\title{
The Effects of Gold Nanoparticles on Leydig Cells and Male Reproductive Function in Mice
}

This article was published in the following Dove Press journal:

International Journal of Nanomedicine

\author{
Ying Liu ${ }^{1}, *$ \\ Xiaojie $\mathrm{Li}^{1, *}$ \\ Shuwen Xiao (D) \\ Xinyi Liu' \\ Xuanming Chen' \\ Qiyue Xia' \\ Song Lei ${ }^{2}$ \\ Hongxia $\mathrm{Li}^{1}$ \\ Zhihui Zhong ${ }^{3}$ \\ Kai Xiao (D)
}

'National Chengdu Center for Safety Evaluation of Drugs and National Clinical Research Center for Geriatrics, West China Hospital, Sichuan University, Chengdu 61004I, People's Republic of China; ${ }^{2}$ Department of Pathology, West China Hospital, Sichuan University, Chengdu 61004I, People's Republic of China; ${ }^{3}$ Laboratory of Non-Human Primate Disease Model Research, West China Hospital, Sichuan University, Chengdu 61004I, People's Republic of China

*These authors contributed equally to this work
Correspondence: Kai Xiao

Tel +86-28-83326313

Email xiaokaikaixiao@scu.edu.cn
Background: Gold nanoparticles (AuNPs) have shown great promise in various biomedical applications, but their effects on male reproductive function remain to be ascertained. The aim of this study was to investigate the uptake, cytotoxicity and testosterone production inhibition of AuNPs in mouse Leydig cells, as well as their accumulation in the testes of male mice and their effects on male reproductive function.

Results: AuNPs ( $5 \mathrm{~nm}$ ) were able to be internalized into the endosomes/lysosomes of TM3 Leydig cells, induce the formation of autophagosomes, increase the production of reactive oxygen species (ROS), and disrupt the cell cycle in S phase, resulting in concentrationdependent cytotoxicity and DNA damage. Interestingly, AuNPs significantly reduced testosterone production in TM3 cells by inhibiting the expression of $17 \alpha$-hydroxylase, an important enzyme in androgen synthesis. After repeated intravenous injection, AuNPs gradually accumulated and retained in the testes of male BALB/c mice in a dosedependent manner. One week after withdrawal, the level of plasma testosterone in the $0.5 \mathrm{mg} / \mathrm{kg}$ AuNPs group was significantly reduced compared to that in the PBS control group, accompanied by the decreased expression of $17 \alpha$-hydroxylase in the testes. In addition, AuNPs treatment significantly increased the rate of epididymal sperm malformation, but without affecting fertility.

Conclusion: Our results suggest that AuNPs can accumulate in the testes and reduce testosterone production in Leydig cells by down-regulating the expression of $17 \alpha-$ hydroxylase, thus affecting the quality of epididymal sperm.

Keywords: gold nanoparticles, Leydig cells, testosterone, reproductive toxicity, fertility

\section{Introduction}

Gold nanoparticles (AuNPs) have been widely used in drug/gene delivery, ${ }^{1,2}$ cancer-targeted therapy, ${ }^{3}$ photothermal therapy $(\mathrm{PTT})^{4}$ and diagnostic imaging, ${ }^{5}$ due to their high stability, relatively easy synthesis, chemical inertness and facile ability to combine ligand. Gold is generally considered to be chemically inert and biocompatible, but due to its small size and large surface area, AuNPs may have higher bioactivity than bulk gold. The increasing use of AuNPs in biomedical fields has raised concerns about their in vivo fate and potential toxic effects in biological organisms, especially in humans. In recent years, toxic effects of AuNPs on primary and secondary target organs such as liver, lung and kidney have been reported, , $^{6}$ which are influenced by various factors, such as physical and chemical properties (eg, size, shape and surface chemistry), method of entry and duration of exposure. For example, spherical AuNPs were taken up more efficiently than gold nanorods, ${ }^{8}$ while small AuNPs (4 and $13 \mathrm{~nm}$ ) showed more widespread organ distribution and 
longer residence time than large AuNPs (100 nm). ${ }^{9}$ Oxidative stress is considered to be a common mechanism of AuNPs-induced toxicity, which activates NF- $\kappa \mathrm{B}$ signaling by up-regulating the transcription of pro-inflammatory genes such as IL-1, IL-6, IL-8 and TNF-a, resulting in DNA damage and apoptosis. ${ }^{10}$ For instance, we have previously shown that a certain size $(5 \mathrm{~nm})$ of AuNPs can induce DNA damage in HepG2 hepatoma cells in comet assay and chromosomal damage in mammalian in vivo micronucleus test, mainly due to the increase in the production of reactive oxygen species (ROS). ${ }^{11}$

It is well known that human male reproductive system is relatively vulnerable to exogenous substances, ${ }^{12}$ and oxidative stress is one of the main mechanisms of its deterioration. $^{13,14}$ In somatic cells, NPs-induced ROS can cause inflammation and even malignant transformation. ${ }^{15}$ However, such damage in sperm cells or supporting somatic cells may result in impaired fertility and/or congenital defects in the offspring. ${ }^{16}$ Despite concerns about the potential adverse effects of AuNPs on male reproductive health, few studies have been reported so far. Wiwanitkit et $\mathrm{al}^{17}$ directly examined the effects of AuNPs $(9 \mathrm{~nm})$ on germ cells by mixing them with fresh semen sample from a healthy male. It was found that after 15 minutes of exposure to $44 \mathrm{ppm}$ of AuNPs, human sperm fragmented and clumped, resulting in immobility in $25 \%$ of the sperm. However, it is unclear whether human sperm will be directly exposed to such a high level of AuNPs under clinically relevant conditions. So far, there is no information about the human exposure of AuNPs. It was reported that the average concentration of $\mathrm{Au}$ element in the whole blood of normal people was about $0.05 \mathrm{ng} / \mathrm{g},{ }^{18}$ and that in platelets was about 0.23 ng/g. ${ }^{19}$ The blood-testis barrier (BTB) is a structural and physiologic compartment formed by basal tight junctions between adjacent Sertoli cells of the seminiferous tubules, which protects developing germ cells from harmful toxicants and auto-immune destruction. ${ }^{20}$ There is limited evidence that certain AuNPs can penetrate the bloodtestis barrier (BTB) and enter the testis in animal models. ${ }^{21}$ For example, Lee et $\mathrm{al}^{22}$ reported that neutral charged polyethylene glycol-coated AuNPs (15 nm) were able to accumulate in the testis of mice after intravenous injection, whereas there was no evidence of the presence of silica-AuNPs $(70 \mathrm{~nm})$ in the testis of mice even 45 days after intramuscular administration. ${ }^{23} \mathrm{Li}$ et $\mathrm{al}^{21}$ showed the deposition of AuNPs in the testicular spermatogonium of male mice after exposure to $45 \mathrm{mg} / \mathrm{kg}$ PEGylated AuNPs, without affecting sperm quality and fertility. Similarly, Chen et $\mathrm{al}^{24}$ showed that a single dose of AuNPs $(7.85 \mathrm{mg} / \mathrm{kg})$ exposure in mice did not induce toxic effects in the male reproductive system. On the other hand, repeated intraperitoneal injection of $200 \mu \mathrm{g} / \mathrm{kg} /$ day AuNPs (10-30 nm) for 35 days significantly affected sperm parameters (motility and morphology) and increased the number of abnormal spermatozoa in male mice. $^{25}$ Overall, whether AuNPs can penetrate the BTB and accumulate in testicular tissue, whether they can affect male reproductive function and their associated mechanisms are still unclear, which deserves to be further investigated.

AuNPs may impair testicular functions in a variety of ways, including changes in testicular histology, decreased sperm quality, reduced fertility, and alteration in testosterone levels. ${ }^{26}$ Previous studies have mostly focused on the effects of AuNPs on male germ cells, with less attention on interstitial cells such as Leydig cells. Leydig cells are located in the interstitial compartments of testis, responsible for the production of testosterone, which is essential for the normal development of male sex organs and sperm maturation. In this study, we first assessed the direct effects of commercial and well-characterized AuNPs (5 $\mathrm{nm})$ on mouse Leydig cells, including cellular uptake, viability and testosterone production. Subsequently, we further investigated whether repeated intravenous administration of AuNPs in male BALB/c mice can accumulate in the testis and affect male reproductive function, including plasma testosterone levels, testicular histopathological changes, sperm quality and fertility.

\section{Materials and Methods Materials}

AuNPs (5 nm, OD = 1, Lot\# MKBQ0180V, without modified functional groups on the surface) stabilized in $0.1 \mathrm{mM}$ PBS, were purchased from Sigma-Aldrich (St. Louis, MO, USA). The concentration of AuNPs suspension was 5.5 E+13 particles/mL. AuNPs were directly diluted to the final concentrations with PBS before use. TM3 cells were purchased from Shanghai Cell Bank, Chinese Academy of Sciences (Shanghai, China). Testosterone ELISA kit was purchased from USCN (Wuhan, China). Human Chorionic Gonadotropin (HCG) was obtained from the second affiliated West China hospital, Sichuan University. Rabbit anti-StAR antibody was purchased from CST (Danvers, MA, USA) and Rabbit anti-Cytochrome P450 17A1 (17 $\alpha$-hydroxylase) 
antibody was purchased from Abcam (Cambridge, MA, USA). All other reagents were purchased from SigmaAldrich (St. Louis, MO, USA).

\section{Characterization of AuNPs}

The morphology of AuNPs was observed on a Tecnai G2 F20 transmission electron microscope (TEM) with an acceleration voltage of $80 \mathrm{kV}$. One drop of the AuNPs suspension was deposited on a TEM grid, dried, evacuated, and submitted to TEM observation. The particle size and stability of AuNPs in PBS and cell culture medium with $5 \%$ horse serum and $2.5 \%$ fetal bovine serum (FBS) were measured by dynamic light scattering (DLS) as described previously. ${ }^{27,28}$ The zeta potential of AuNPs was measured by NanoBrook Omni (Brookhaven).

\section{Cell Culture}

TM3 cells were cultured in F12-DMEM medium supplemented with 100 units $/ \mathrm{mL}$ penicillin, 100 units $/ \mathrm{mL}$ streptomycin, 5\% horse serum and $2.5 \% \mathrm{FBS}$ at $37{ }^{\circ} \mathrm{C}$ in incubator supplemented with $5 \% \mathrm{CO}_{2}$.

\section{Cellular Uptake}

The uptake of AuNPs in TM3 cells were qualitatively observed by TEM. Briefly, TM3 cells were co-incubated with AuNPs $(5 \mu \mathrm{g} / \mathrm{mL})$ for $24 \mathrm{~h}$, then washed with cold PBS, fixed with $3 \%$ glutaraldehyde, post-fixed with $1 \%$ osmium tetroxide, dehydrated in gradient ethanol, embedded in a mixture of EPON resin in propylene oxide polymerized, and finally ultramicrotombed. TEM images were acquired at an acceleration voltage of $100 \mathrm{kV}$.

The internalization of AuNPs in TM3 cells were quantitatively determined by inductively coupled plasma mass spectrometry (ICP-MS). Briefly, TM3 cells were seeded into 6-well plates, and treated with different concentrations of AuNPs for $24 \mathrm{~h}$, or with AuNPs $(5 \mu \mathrm{g} / \mathrm{mL})$ for different periods of time, respectively. After treatment, the cells were collected and placed into a digestion vial with $1 \mathrm{~mL}$ of aqua regia (mixture of nitric acid and hydrochloric acid in a molar ratio of 1:3). The mixture was treated under microwave conditions, including a 15 min warming up to $140{ }^{\circ} \mathrm{C}$, and another 15 min warming up to $190{ }^{\circ} \mathrm{C}$ and hold on $30 \mathrm{~min}$. The gold content of these samples was analyzed by ICP-MS (Thermo X2). The quantification was carried out by external point calibration with internal standard correction. The main instrumental operating conditions were as follows: RF power $1500 \mathrm{~W}$ and gas flow $0.88 \mathrm{~L} / \mathrm{min}$ air. Au level was expressed as $\mathrm{ng} / \mathrm{mL}$ and the experiments were repeated three times. The detection limit of gold concentration is $0.02 \mathrm{ng} / \mathrm{mL}$.

\section{In vitro Cytotoxicity}

TM3 cells were seeded in 96-well plates, and treated with different concentrations of AuNPs for $24 \mathrm{~h}, 48 \mathrm{~h}, 72 \mathrm{~h}$ and $96 \mathrm{~h}$, respectively. Since the concentration of the AuNPs stock solution is $50 \mu \mathrm{g} / \mathrm{mL}$, the maximum concentration in the cytotoxicity experiment was set at $12.5 \mu \mathrm{g} / \mathrm{mL}$. After treatment, MTT reagent was added to each well and further incubated for another $4 \mathrm{~h}$. The absorbance at 570 nm was detected. Untreated cells served as a control. Results were shown as the average cell viability $\left[\left(\mathrm{OD}_{\text {treat }}\right.\right.$ $\left.\mathrm{OD}_{\text {blank }}\right) /\left(\mathrm{OD}_{\text {control }}-\mathrm{OD}_{\text {blank }}\right) \times 100 \%$ ] of triplicate wells.

\section{Comet Assay}

DNA damage in TM3 cells after exposure to AuNPs was evaluated by Comet assay as previously described. ${ }^{29,30}$ In brief, cells were plated in 12-well plates at the initial density of 50, 000 cells per well, and treated with PBS (negative control), $2 \mu \mathrm{M} \quad \mathrm{K}_{2} \mathrm{Cr}_{2} \mathrm{O}_{7}$ (positive control, $2-\mathrm{h}$ incubation), and different concentrations of AuNPs for $4 \mathrm{~h}$ and $24 \mathrm{~h}$, respectively. After treatment, cells were trypsinized, washed with PBS and re-suspended in $0.8 \%$ low melting-temperature agarose (LMPA) at the density of $1 \times 10^{5}$ cells $/ \mathrm{mL}$. The cell suspension was then poured on slides previously covered with $1 \%$ normal meltingtemperature agarose (NMPA). After the agarose solidification at $4{ }^{\circ} \mathrm{C}$, another layer of LMPA was added and allowed to solidify. After lysis in $4{ }^{\circ} \mathrm{C}$ for $1 \mathrm{~h}$, slides were placed in a gel electrophoresis tank and incubated in an alkaline $(\mathrm{pH} \geq 13)$ electrophoresis solution for $30 \mathrm{~min}$ to allow DNA unwinding. After electrophoresis (25 V, 300 $\mathrm{mA}, 28 \mathrm{~min}$ ) and neutralization, slides were fixed in $75 \%$ ethanol for $5 \mathrm{~min}$ and dried. Rehydrated samples were stained with Ethidium Bromide (EB, $30 \mu \mathrm{g} / \mathrm{mL}$ ) for 15 min and examined using a fluorescence microscope. Images of 100 randomly selected cells from each dose were recorded and analyzed using CASP software. The $\%$ DNA in tail was chosen as a parameter for further analysis of DNA damage.

\section{ROS Measurement}

Intracellular ROS production was detected using DCF-DA fluorescence probe. Briefly, TM3 cells $\left(10^{5}\right.$ cells/well $)$ were seeded onto 6-well culture plate and incubated with AuNPs $(12.5 \mu \mathrm{g} / \mathrm{mL})$ for $24 \mathrm{~h}$. Then, the cells were treated 
with $10 \mu \mathrm{M}$ DCF-DA for $2 \mathrm{~h}$ at $37^{\circ} \mathrm{C}$. The cells were washed and subjected to observation under confocal fluorescence microscopy. For quantitative analysis, the ROS fluorescence intensity of cells was measured by flow cytometry, and approximately $1 \times 10^{4}$ counts were collected for each sample.

\section{Apoptosis and Cell Cycle}

TM3 cells were treated with AuNPs $(12.5 \mu \mathrm{g} / \mathrm{mL})$ for 72 h. Then, cells were harvested, stained with Annexin V-FITC and PI for $30 \mathrm{~min}$, and analyzed by flow cytometry.

TM3 cells were incubated with different concentrations of AuNPs for $72 \mathrm{~h}$, respectively. Cells were trypsinized, washed with PBS, fixed in $75 \%$ ethanol, and stored at $4{ }^{\circ} \mathrm{C}$ overnight. Then, cells were washed twice with ice-cold PBS, resuspended in $0.5 \mathrm{~mL}$ PBS with $240 \mu \mathrm{g} / \mathrm{mL}$ propidium iodide (PI) and $100 \mu \mathrm{g} / \mathrm{mL}$ RNase A, and incubated for $30 \mathrm{~min}$ in the dark. Cell cycle distribution was measured with FACS calibur flow cytometer (BD Bioscience), and analyzed with ModFit LT software. Samples were repeated in triplicate.

\section{Testosterone Production in TM3 Cells}

TM3 cells were incubated for $24 \mathrm{~h}$ with PBS control or different concentrations of AuNPs in the presence or absence of HCG (1 unit/2mL medium), respectively. The testosterone levels in culture medium samples were determined by ELISA kit, according to the manufacturer's instructions. Testosterone level was expressed as $\mathrm{ng} / \mathrm{mL}$ media and each cell sample was repeated for three times.

After the same exposure to AuNPs as above, TM3 cells were lysed in cold RIPA lysate buffer and the total protein was quantitated by bicinchoninic acid (BCA) assay. The lysate was separated on $12 \%$ SDS-PAGE and transferred to polyvinylidene difluoride membrane. The membrane was incubated overnight at $4^{\circ} \mathrm{C}$ with primary antibodies (anti-StAR, $17 \alpha$-hydroxylase and $\beta$-actin), then washed with TBST buffer, and incubated with horseradish peroxidase-conjugated secondary antibodies. Immuno-reactive bands were detected by the exposure to x-ray film.

\section{In vivo Distribution and Toxicity of AuNPs in Male Reproductive System}

BABL/c mice (4 weeks old) were purchased from Vital River Laboratories (Beijing, China). All mice were kept under specific pathogen free (SPF) conditions with a 12-h light/dark cycle at a temperature of approximately $24{ }^{\circ} \mathrm{C}$ and a relative humidity of $45 \%$. Mice were divided into 5 mice/cage and provided with diet and tap water ad libitum. All experiments were performed in compliance with the Association for Assessment and Accreditation for Laboratory Animal Care (AAALAC) guidelines and the protocols approved by the Institutional Animal Care and Use Committee of West China Hospital, Sichuan University.

After 5 days of acclimatization, the male mice were randomly divided into three groups $(\mathrm{n}=12 /$ group $)$ and were intravenously injected with PBS control, $0.17 \mathrm{mg} / \mathrm{kg}$ AuNPs and $0.50 \mathrm{mg} / \mathrm{kg}$ AuNPs once a day for 14 consecutive days (cumulative doses of $2.38 \mathrm{mg} / \mathrm{kg}$ and $7 \mathrm{mg} /$ $\mathrm{kg}$ ), respectively. According to our previous reports, ${ }^{11,31}$ since the concentration of AuNPs stock solution was 50 $\mu \mathrm{g} / \mathrm{mL}$ and the injection volume was $0.1 \mathrm{~mL} / 10 \mathrm{~g}$ body weight, the high dose of AuNPs in this study was set at $0.50 \mathrm{mg} / \mathrm{kg}$. At $24 \mathrm{~h}$ after the last administration, half of male mice $(\mathrm{n}=6)$ in each group were anesthetized with pentobarbital, and blood samples were collected from orbital vein, and the plasma were frozen at $-80{ }^{\circ} \mathrm{C}$ for testosterone determination. Bilateral epididymis was rapidly dissected for sperm evaluation. Left testis was removed, weighed, and frozen in $-80{ }^{\circ} \mathrm{C}$ for Au measurement by ICP-MS. Right testis was fixed in $2.5 \%$ glutaraldehyde for TEM analysis, or in Davidson's solution for histopathological analysis. ${ }^{32}$ The remaining half of the male mice were used to assess the fertility by mating with untreated female mice (1:2) for a week. At the end of the experiment, all the remaining male mice were euthanized and blood and organs were collected for the above measurements.

\section{Determination of $\mathrm{Au}$ in Testicular Tissue by ICP-MS}

Left testis was placed into a digestion vial with $6 \mathrm{~mL}$ of aqua regia, and treated under microwave conditions, including a $15 \mathrm{~min}$ warming up to $140{ }^{\circ} \mathrm{C}$, and another $15 \mathrm{~min}$ warming up to $190{ }^{\circ} \mathrm{C}$ and hold on $30 \mathrm{~min}$. Afterwards the mixture was transferred to volumetric flask, and aqua regia was added to a total volume of $10 \mathrm{~mL}$. Internal standard $\mathrm{Rh}$ (final concentration of $10 \mathrm{mg} / \mathrm{L}$ ) was injected prior to the measurement. The quantification was carried out by external point calibration with internal standard correction. Standards and samples were analyzed with ICP-MS. The main instrumental operating conditions were as follows: RF power $1500 \mathrm{~W}$ and gas flow $0.88 \mathrm{~L} / \mathrm{min}$ air. $^{33,34} 197 \mathrm{Au}$ and 
103Rh were chosen as internal standards, and Au level was expressed as $\mathrm{ng} / \mathrm{g}$ tissue.

\section{Sperm Evaluation}

After dissection, epididymis was minced in $1 \mathrm{~mL}$ of $0.5 \%$ bovine serum albumin (BSA), and incubated at $37{ }^{\circ} \mathrm{C}$ for several minutes to release sperm. The sperm concentration was calculated using the hemocytometer, and the movement of 200 sperm cells was examined using a light microscope. For the assessment of sperm morphology, the sperm was stained with $1 \%$ eosin dissolved in $80 \%$ ethyl alcohol, and 1000 sperms from each mouse were examined.

\section{Fertility Evaluation}

The remaining half male mice $(n=6)$ were caged with two untreated virgin females for one week, and then the females were separated from males. Pregnant mice were observed at least twice daily to determine the time of birth. Pregnant mice were dissected after anesthesia with pentobarbital sodium at the day before birthday. The number of pups, resorption embryos and number of live pups were recorded. Copulation index $(\%)=($ No. of animals with successful copulation/No. of animals paired) $\times 100$. Fertility index $(\%)=$ (No. of pregnant females/No. of females with successful copulation) $\times 100$. Gestation index $(\%)=($ No. of females that delivered live pups/No. of pregnant females) $\times 100$.

\section{Statistical Analysis}

All data were analyzed using SPSS software (version 16) by one-way analysis of variance (ANOVA) for multiple groups followed by Student Newman Keul's test. Data were expressed as mean \pm standard deviation (SD). The value of $P<0.05$ was considered statistically significant.

\section{Results}

\section{Physicochemical Characterization of AuNPs}

Based on the specification information provided by the manufacturer, the core size and hydrodynamic diameter of $5 \mathrm{~nm}$ AuNPs used in this study was $3-7 \mathrm{~nm}$ and $7-$ $20 \mathrm{~nm}$, respectively, and its polydispersity index (PDI) was $<0.2$. TEM images (Figure 1A) demonstrated that the AuNPs were spherical and homogeneous, and the particle size was about $5-10 \mathrm{~nm}$ in diameter, which was also consistent with the data obtained by DLS measurement
(Figure 1B). The stability in particle size of AuNPs in the presence of culture medium with $5 \%$ horse serum and $2.5 \%$ FBS was also monitored by DLS. As shown in (Figure S-1A), no obvious precipitation or aggregates were found when AuNPs were incubated in culture medium for $72 \mathrm{~h}$, and their particle size remained unchanged, indicating that the AuNPs were relatively stable. The zeta potential of AuNPs were $-27 \mathrm{mV}$ (Figure S-1B)

\section{Cellular Uptake of AuNPs in TM3 Cells}

The cellular uptake and internalization of AuNPs in TM3 cells were qualitatively visualized by TEM. After 24-h incubation, AuNPs were able to be taken up by TM3 cells, and most of them were distributed in intracellular compartments such as endosomes/lysosomes, but not in the nucleus (Figure 1C, left panel). After 48-h and 72-h incubation, the intake of AuNPs in TM3 cells increased and was still mainly distributed in the endosomes/lysosomes (Figure S-2). Moreover, AuNPs may induce the formation of autophagosomes, and AuNPs were also present in some autophagosomes (Figure 1C, right panel). Meanwhile, the uptake of AuNPs in TM3 cells was also quantitatively determined by ICP-MS. The results demonstrated that AuNPs can be internalized into TM3 cells in a concentration-dependent manner (Figure 1D). For example, after 24-h incubation, the gold amount in TM3 cells exposed to $1.67 \mu \mathrm{g} / \mathrm{mL}, 5 \mu \mathrm{g} / \mathrm{mL}$ and $12.5 \mu \mathrm{g} / \mathrm{mL}$ AuNPs were $13.8 \pm 1.0 \mathrm{ng} / \mathrm{L}, 29.1 \pm 1.3 \mathrm{ng} / \mathrm{L}$ and $49.2 \pm 9.0 \mathrm{ng} / \mathrm{L}$, respectively. However, the uptake of AuNPs in TM3 cells was not completely time-dependent (Figure 1E). For instance, the gold content of TM3 cells after 48-h exposure of $5 \mu \mathrm{g} / \mathrm{mL}$ AuNPs $(29.3 \pm 0.3 \mathrm{ng} / \mathrm{L})$ was significantly higher than that of cells after 24-h exposure $(12.2 \pm 0.2 \mathrm{ng} /$ L), but there was no further increase after 72-h exposure $(25.9 \pm 2.9 \mathrm{ng} / \mathrm{L})$, indicating that the uptake of AuNPs was saturated at $48 \mathrm{~h}$.

\section{Cytotoxicity of AuNPs Against TM3 Cells and Underlying Mechanisms}

The effect of AuNPs on the viability of TM3 cells was evaluated by MTT assay. As illustrated in Figure 2A, AuNPs exhibited time - and concentration - dependent cytotoxicity. After 24-h incubation, AuNPs had no obvious cytotoxic effect on TM3 cells at the tested concentrations. After 48-h incubation, the viability of cells treated with 12.5 $\mu \mathrm{g} / \mathrm{mL}$ AuNPs decreased significantly compared to the PBS control $(P<0.05)$. After 72 and $96-\mathrm{h}$ of incubation, the cell 
A

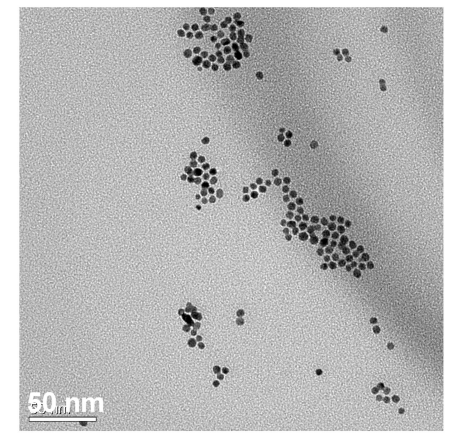

B

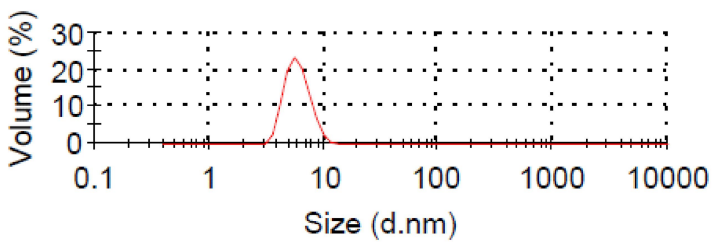

C
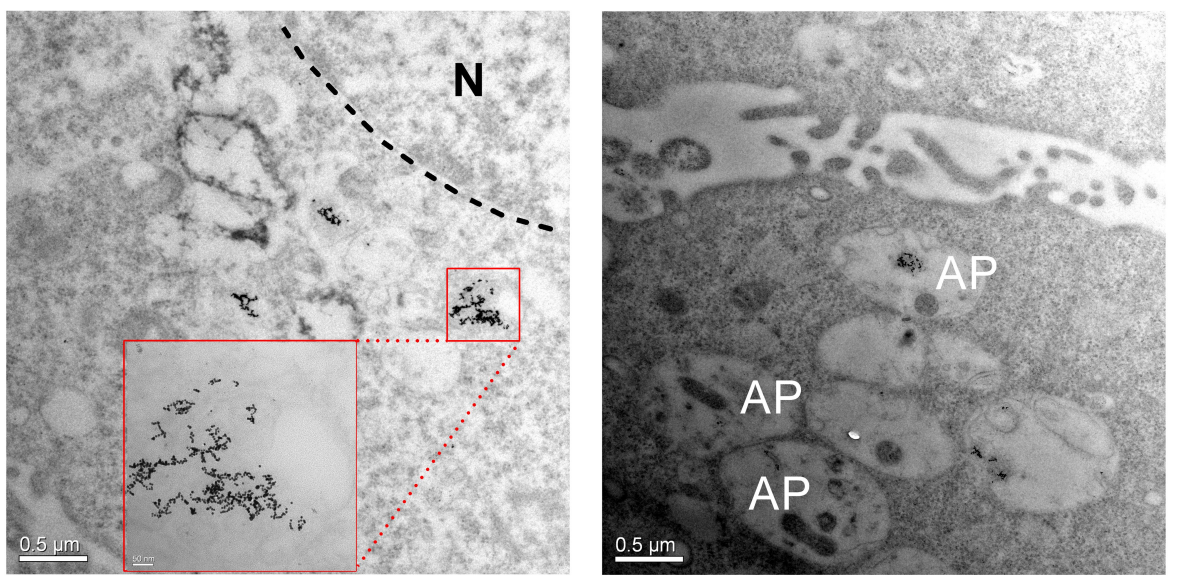

D

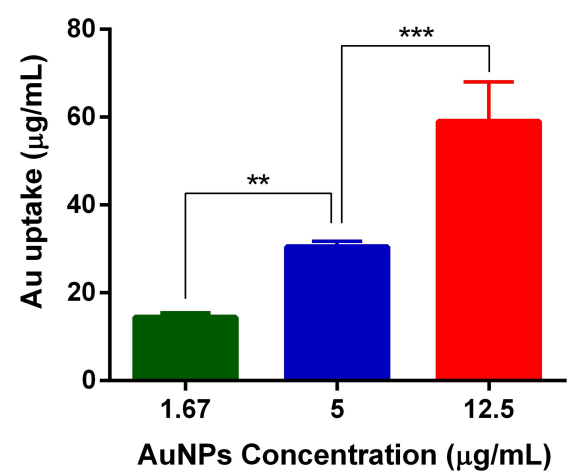

E

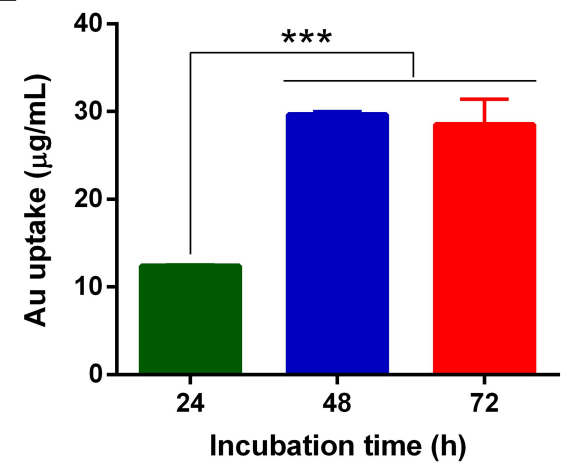

Figure I Physicochemical characterizations of AuNPs and their uptake in TM3 Leydig cells. (A) Transmission electron microscopy (TEM) images of AuNPs. Scale bars $=50$ nm. (B) Particle size of AuNPs measured by dynamic light scattering (DLS). (C) Representative TEM images of TM3 cells after 24-h exposure of AuNPs (5 $\mu$ g/mL). AuNPs were mainly entrapped in the endosome/lysosome but not in the nucleus $(\mathrm{N})$. In addition, they may induce autophagy and were present in some autophagosomes (AP). The concentration (D) and time (E) dependent uptake of AuNPs in TM3 cells determined by inductively coupled plasma mass spectrometry (ICP-MS). TM3 cells were incubated with different concentrations of AuNPs for $24 \mathrm{~h}$, or with $5 \mu \mathrm{g} / \mathrm{mL}$ AuNPs for different periods of time, respectively. Results are shown as mean \pm SD ( $\mathrm{n}=3$ ). $* * P<0.0 \mathrm{I}$, $* * *$ $P<0.001$.

viability of each AuNPs group was further reduced, which was concentration-dependent $(P<0.01)$.

DNA damage of TM3 cells treated with AuNPs was detected by comet assay. As shown in the representative images (Figure 2B), no DNA damage was found in the cells treated with PBS control, while significant DNA breakage (comet tail) was observed in some cells treated with $\mathrm{K}_{2} \mathrm{Cr}_{2} \mathrm{O}_{7}$ positive control and AuNPs $(5 \mu \mathrm{g} / \mathrm{mL}$ and above). In addition, AuNPs-induced DNA damage of TM3 cells was time - and concentration - dependent. For example, after 4-h incubation, the average percentage of tail DNA in $1.67 \mu \mathrm{g} / \mathrm{mL}, 5 \mu \mathrm{g} / \mathrm{mL}$ and $12.5 \mu \mathrm{g} /$ $\mathrm{mL}$ AuNPs groups was 0.90, $3.92(P<0.01)$, and 8.16 $(P<0.01)$, respectively, which was significantly higher than that (0.36) in PBS control group. After 24-h incubation, the average percentage of tail DNA in $1.67 \mu \mathrm{g} /$ 
A

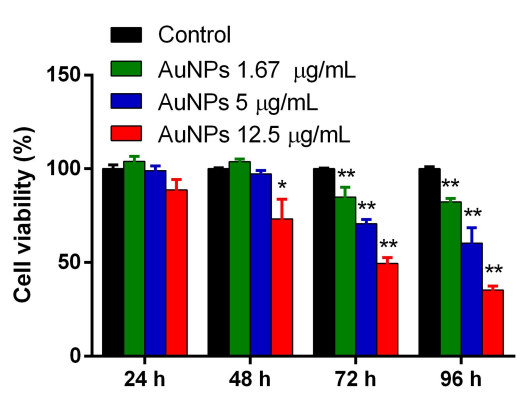

C

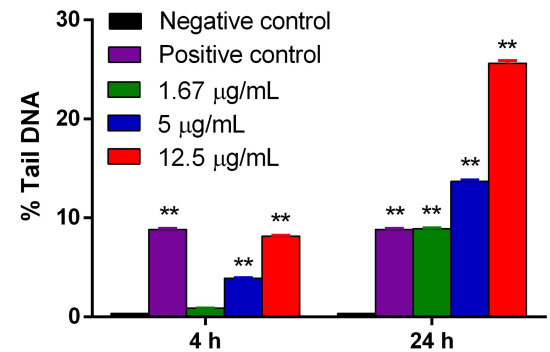

B

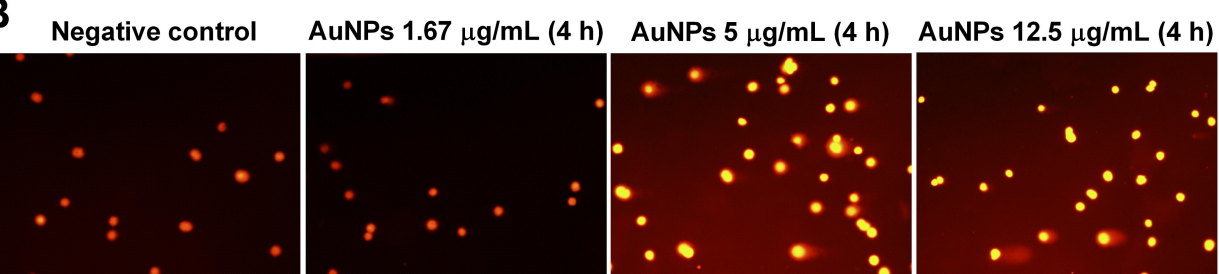

Positive control AuNPs $1.67 \mu \mathrm{g} / \mathrm{mL}(24 \mathrm{~h})$ AuNPs $5 \mu \mathrm{g} / \mathrm{mL}(24 \mathrm{~h})$ AuNPs $12.5 \mu \mathrm{g} / \mathrm{mL}(24 \mathrm{~h})$
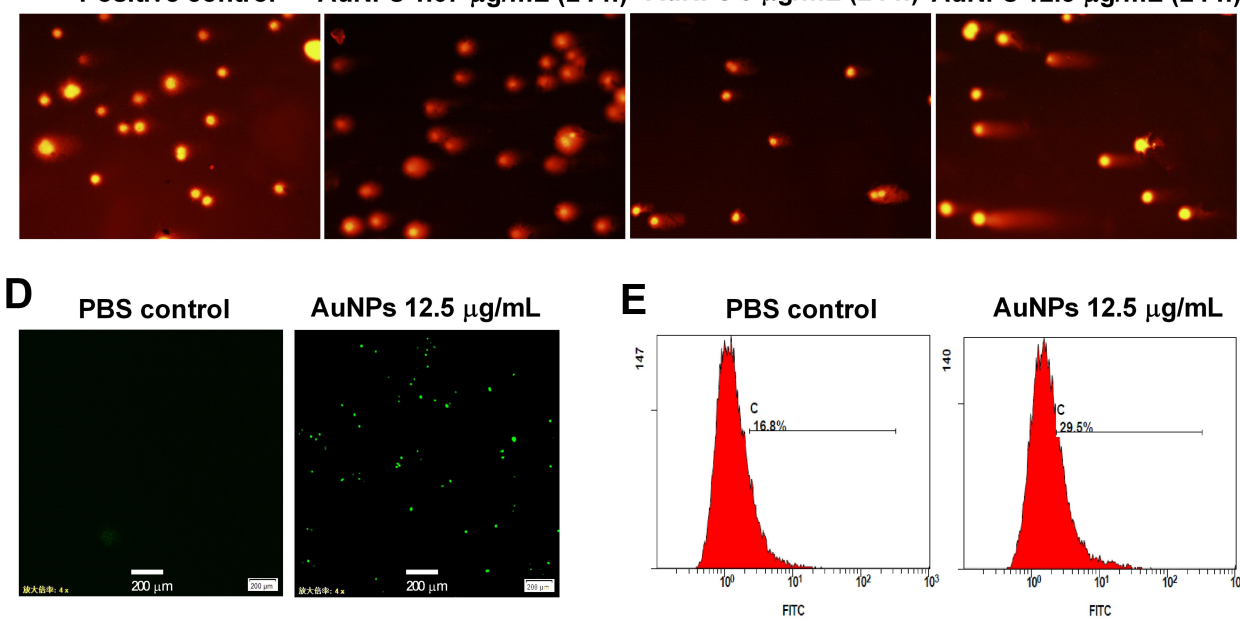

AuNPs $12.5 \mu \mathrm{g} / \mathrm{mL}$

F
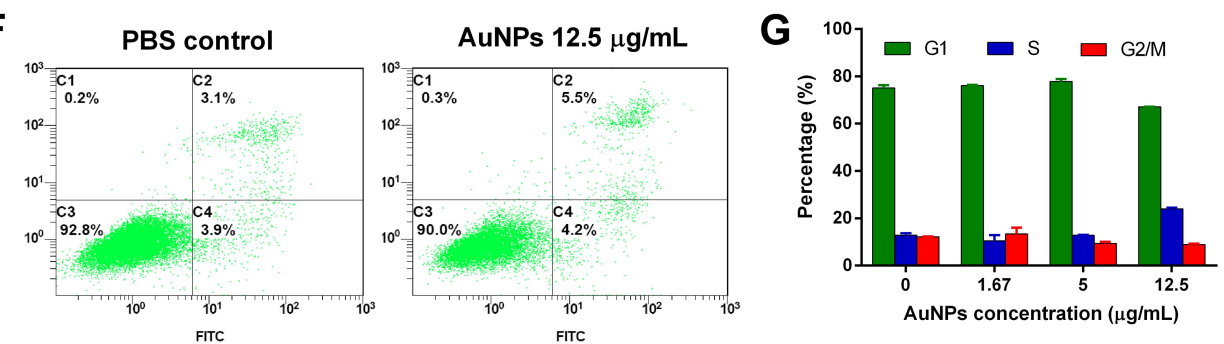

Figure 2 AuNPs-induced cytotoxicity and DNA damage in TM3 Leydig cells and their potential mechanisms. (A) The cell viability of AuNPs against TM3 cells was measured by MTT assay. (B) Representative images in the comet assay. (C) The DNA damage of TM3 cells exposed to different concentrations of AuNPs for $4 \mathrm{~h}$ or $24 \mathrm{~h}$ was measured by comet assay. Images of 100 randomly selected cells were analyzed using CASP software, and \% DNA in the tail was chosen as a DNA damage parameter. Results are shown as mean $\pm \mathrm{SD}(\mathrm{n}=3) . * P<0.05$, ** $P<0.0$ I, compared to negative control. The intracellular ROS production in TM3 cells treated with AuNPs $(I 2.5 \mu g / \mathrm{mL})$ was detected by confocal fluorescence microscopy (D) and flow cytometry (E), respectively. Scale bar: $200 \mu$ m. (F) Apoptotic or necrotic cell death of TM3 cells was detected by flow cytometry after 72-h incubation with $12.5 \mu \mathrm{g} / \mathrm{mL}$ AuNPs, followed by Annexin V-FITC and PI dual-staining. (G) The cell cycle of TM3 cells was analyzed by flow cytometry after 72-h incubation with different concentration of AuNPs. Results are shown as mean \pm SD $(n=3)$.

$\mathrm{mL}, 5 \mu \mathrm{g} / \mathrm{mL}$ and $12.5 \mu \mathrm{g} / \mathrm{mL}$ AuNPs groups further increased to $8.91,13.70$, and 25.62 , respectively (Figure 2C).

The intracellular production of ROS in TM3 cells after AuNPs treatment was measured by DCF-DA staining. ROS-induced oxidative stress is considered to be a common nano-toxic pathway. ${ }^{15}$ As shown in confocal fluorescence images (Figure 2D), AuNPs significantly enhanced the production of intracellular ROS (green) compared to the PBS control, which was further quantitatively confirmed by flow cytometric analysis (Figure 2E). Dual staining with fluorescent Annexin V and PI was used to 
detect apoptotic and necrotic cell death. As shown in Figure $2 \mathrm{~F}$, the total population of apoptotic cells $\left(\mathrm{C}_{2}+\right.$ $\mathrm{C}_{3}, 9.7 \%$ ) in the AuNPs treatment group was slightly higher than that in the control group $(7.0 \%)$, but there was no statistical difference $(P>0.05)$. Cell cycle analysis (Figure 2G) demonstrated that AuNPs treatment significantly increased the percentage of cells in $S$ phase $(23.58 \%)$ with a concomitant decrease in G1 phase
(67.11\%), compare to the corresponding one (S phase: $11.88 \%$, G1 phase: $76.29 \%$ ) in the control group, suggesting that cell cycle was affected.

\section{AuNPs Inhibited Testosterone Synthesis in TM3 Cells}

The effect of AuNPs on testosterone production in TM3 cells was measured by ELISA method. As shown in Figure 3A,

\section{A}

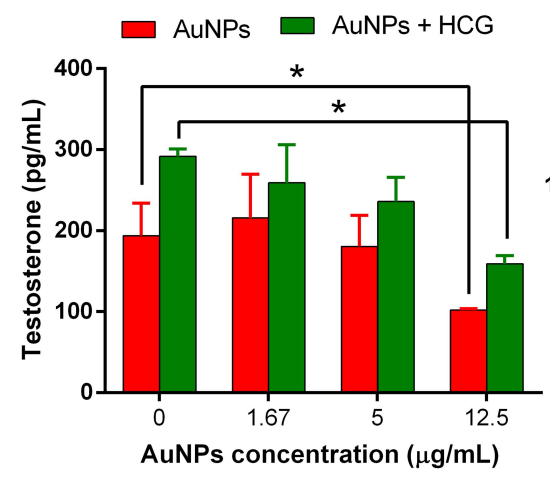

C

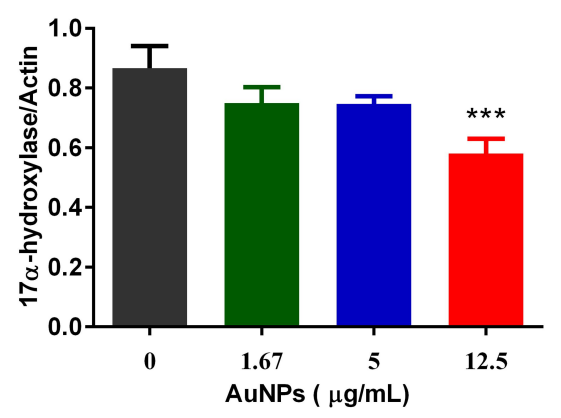

B

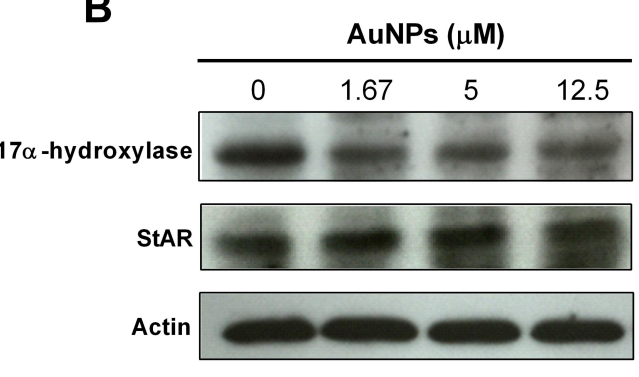

D

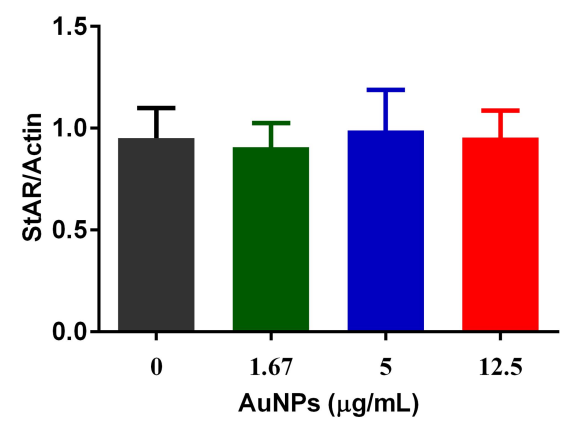

E

Leydig cell

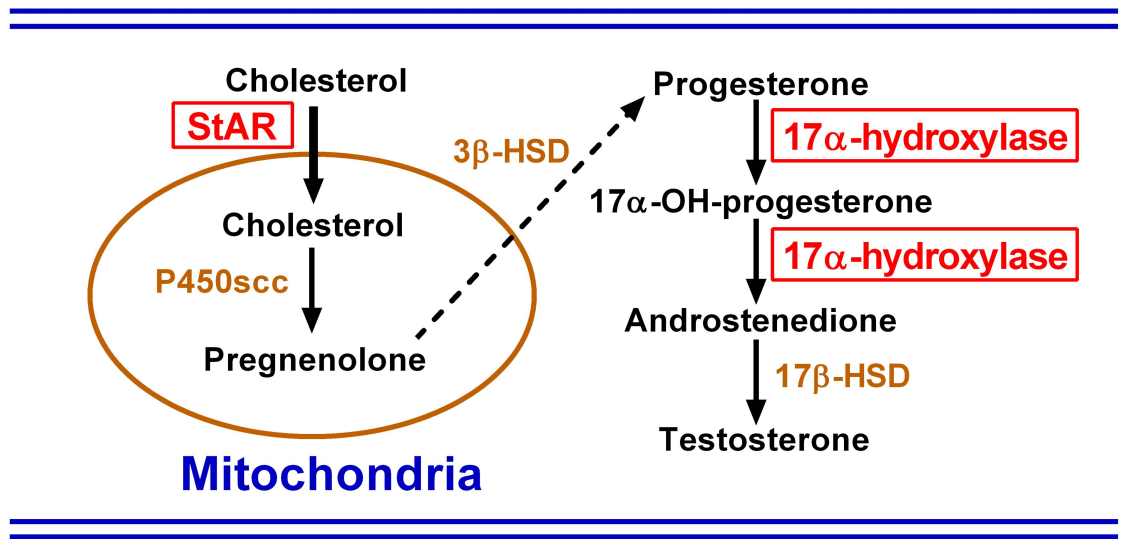

Figure 3 The effect of AuNPs on testosterone production in TM3 cells. (A) Testosterone concentration in the culture medium of TM3 cells after 24-h incubation with indicated concentration of AuNPs in the presence or absence of HCG. (B) Representative Western blot showing the expression of StAR and I7 $\alpha$-hydroxylase in TM3 cells after 24-h incubation with AuNPs. Actin was used as an internal control. The densitometric analysis of I7-hydroxylase (C) and StAR (D) expression relative to Actin in the Western blot. Results are shown as mean \pm SD $(n=3) * P<0.05$, *** $P<0.00$ l, compared to the PBS control. (E) Schematic diagram of testosterone synthesis in Leydig cells. StAR and $17 \alpha$-hydroxylase are two of key proteins involved in the testosterone synthesis. 
AuNPs treatment led to a concentration-dependent decrease of testosterone production in TM3 cells. For example, the testosterone concentration in the culture medium of TM3 cells treated with $12.5 \mu \mathrm{g} / \mathrm{mL}$ AuNPs was $102.0 \pm 1.6 \mathrm{pg} /$ $\mathrm{mL}$, which was significantly lower than that of cells treated with PBS control $(193.9 \pm 40.0 \mathrm{pg} / \mathrm{mL}, P<0.05)$. Although testosterone production in all treatment groups increased under HCG stimulation, the testosterone level in the 12.5 $\mu \mathrm{g} / \mathrm{mL}$ AuNPs group $(159.0 \pm 17.4 \mathrm{pg} / \mathrm{mL})$ was significantly lower than that in the PBS control group $(291.7 \pm 15.7 \mathrm{pg} /$ $\mathrm{mL}, P<0.05)$. StAR is a transport protein mediating the transfer of cholesterol from outer mitochondrial membrane to inner mitochondrial membrane, and $17 \alpha$-hydroxylase is a rate-limiting enzyme that participates in all the rate limiting steps of testosterone synthesis. Representative Western blot images (Figure 3B) and corresponding densitometric analysis (Figure 3C, D) showed no significant change in StAR expression after AuNPs treatment, but significant decrease in $17 \alpha$-hydroxylase expression. Figure $3 \mathrm{E}$ illustrates a schematic diagram of the testosterone synthesis process, where StAR and $17 \alpha$-hydroxylase are two key proteins. ${ }^{35}$

\section{Accumulation of AuNPs in Testis}

As demonstrated in the schematic diagram of experimental design in Figure $4 \mathrm{~A}$, male $\mathrm{BALB} / \mathrm{c}$ mice were injected intravenously with PBS control, $0.17 \mathrm{mg} / \mathrm{kg}$ AuNPs and $0.50 \mathrm{mg} / \mathrm{kg}$ AuNPs once a day for $14 \mathrm{con}$ secutive days, respectively. The body weight of mice in the $0.50 \mathrm{mg} / \mathrm{kg}$ AuNPs group decreased slightly during the administration, but completely recovered 7 days after

A

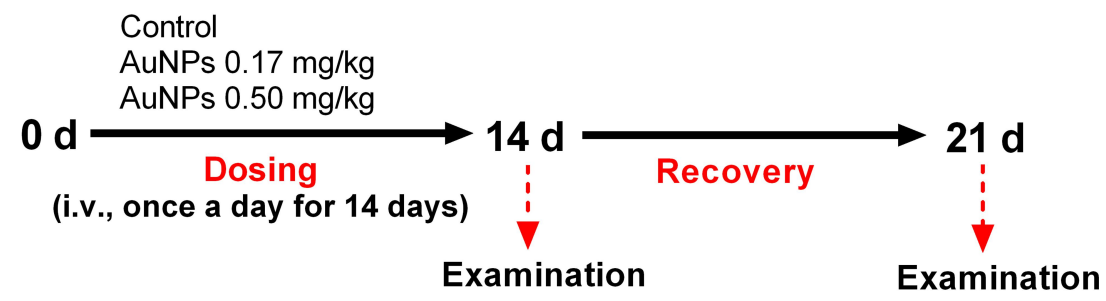

B

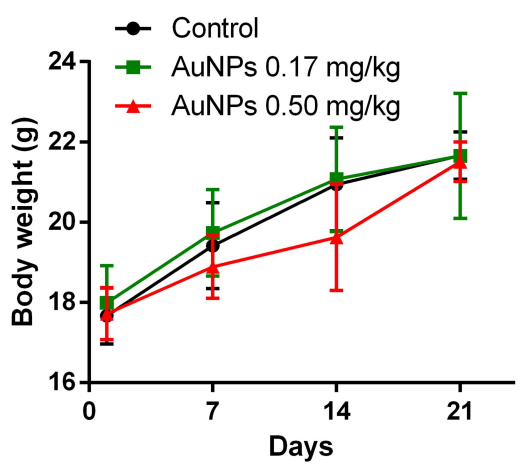

C

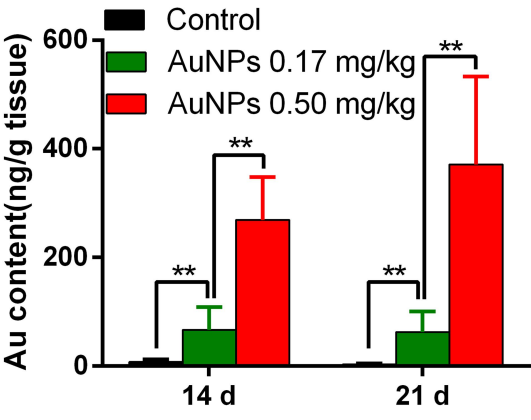

D

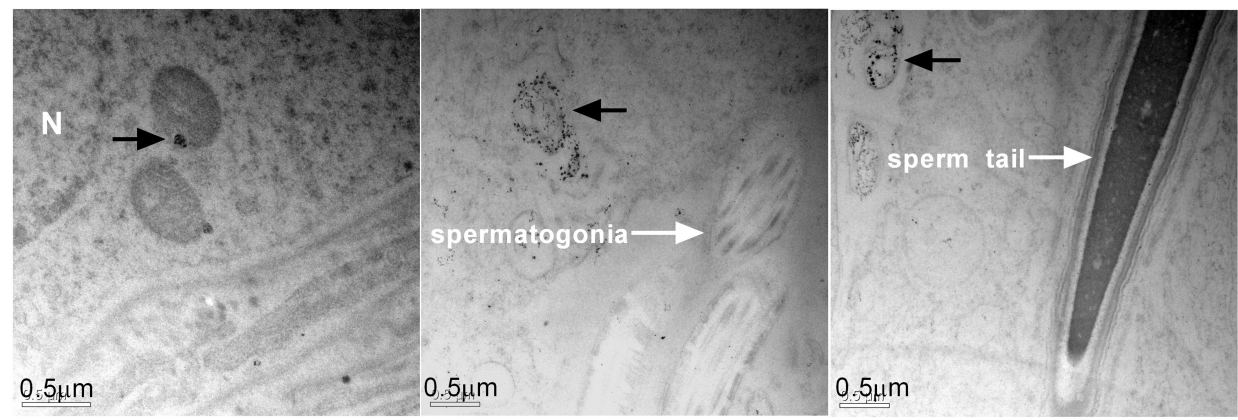

Figure 4 Toxicity and testicular accumulation of AuNPs in mice. (A) Scheme of experimental design in vivo. (B) Body weight of male mice treated with AuNPs throughout the experiment period. (C) ICP-MS analysis of Au contents in the testes of mice treated with AuNPs on days I4 and 2 I ( $n=6$ ). (D) TEM images of testicular sections in mice treated with $0.5 \mathrm{mg} / \mathrm{kg}$ AuNPs on day 14. Black dots (black arrow) in the section were gold nanoparticles, which were obviously present in the testicular section, mainly packed in the vesicles of interstitial cells, but not in the spermatogonia and sperm. The scale bar was $0.5 \mu \mathrm{m}$. $* * P<0.0$ I. 
drug withdrawal (Figure 4B). On day 14 (one day after last dose) and day 21 (one week after recovery), half of mice in each group were euthanized, and the accumulation of AuNPs in testis was analyzed by ICP-MS. As shown in Figure 4C, AuNPs were able to accumulate in the testes in a dose-dependent manner, and stayed there for at least one week. On day 14, the $\mathrm{Au}$ amount of AuNPs in testes of mice treated with $0.17 \mathrm{mg} / \mathrm{kg}$ and $0.50 \mathrm{mg} / \mathrm{kg}$ AuNPs was approximately $66.3 \mathrm{ng} / \mathrm{g}$ and $269.3 \mathrm{ng} / \mathrm{g}$, respectively, which was significantly higher than that in the PBS control group $(7.4 \mathrm{ng} / \mathrm{g}, P<0.05)$. On day 21, the testicular Au content in the $0.17 \mathrm{mg} / \mathrm{kg}$ and $0.50 \mathrm{mg} / \mathrm{kg}$ AuNPs group was $62.4 \mathrm{ng} / \mathrm{g}$ and 370.9 $\mathrm{ng} / \mathrm{g}$, respectively, which was comparable or even higher than that on day 14. This suggests that AuNPs can accumulate gradually in testis, and the clearance rate is relatively slow. TEM images of testicular tissue in AuNPs-treated mice further confirmed that a significant amount of AuNPs were present in different fields of testicular sections, and they were mainly packed in the membrane-bound vesicles of interstitial cells such as Leydig cells, but not in spermatogonia and spermatozoa (Figure 4D and Figure S-3).

\section{Effects of AuNPs on Testicular Weight, Histology and Testosterone Production in Mice}

In view of the significant distribution and retention of AuNPs in testis, it is necessary to investigate their potential male reproductive toxicity. On day 21 , the weight of epididymis in the $0.50 \mathrm{mg} / \mathrm{kg}$ AuNPs group decreased slightly compared to that in the control group $(P<0.05$, Figure 5A). There was no significant difference in testicular weight between AuNPs and PBS control groups on days 14 and 21 (Figure 5B). Histological examination of testis (Figure 5C) demonstrated that there were no obvious morphological changes in germ cells and interstitial cells (including Leydig cells) between AuNPs and PBS control groups.

On day 14, there was no significant difference in plasma testosterone levels between the AuNPs and PBS control groups. However, on day 21, plasma testosterone levels in the $0.50 \mathrm{mg} / \mathrm{kg}$ AuNPs group were significantly lower than those in the PBS control group $(P<0.05$, Figure 5D). Western blot images of testicular tissue (Figure 5E) and the corresponding densitometric analysis (Figure 5F) showed no significant change in StAR expression between
AuNPs and PBS control groups, but the expression of $17 \alpha-$ hydroxylase in the $0.50 \mathrm{mg} / \mathrm{kg}$ AuNPs group was significantly lower than that in the PBS control group on day 14 $(P<0.05)$, which was consistent with the in vitro results obtained in TM3 Leydig cells.

\section{Effects of AuNPs on Sperm Quality and Fertility of Male Mice}

There was no significant change in the concentration (Figure 6A) and motility (Figure 6B) of epididymal sperm between AuNPs and PBS control groups. However, the rate of sperm malformations (including small head, large head, double head, double tail, and coiled tail) in the $0.5 \mathrm{mg} / \mathrm{kg}$ AuNPs group was significantly higher than that in the PBS control group on days 14 and $21(P<0.05$, Figure $6 \mathrm{C})$. As shown in Figure 6D, there were no significant changes in copulation index, fertility index and gestation index between AuNPs and PBS control groups, indicating that the fertility of male mice treated with AuNPs was not significantly affected. Meanwhile, the rates of resorption and stillbirth were comparable between the AuNPs treatment and PBS control groups (data not shown). In addition, the average number of pups/pregnant female mated with male mice in the group of PBS control, $0.17 \mathrm{mg} / \mathrm{kg}$ AuNPs and $0.50 \mathrm{mg} / \mathrm{kg}$ AuNPs were 7.3, 7.0, and 5.8, respectively $(P=0.067$, Figure 6E).

\section{Discussion}

AuNPs present potential health and environmental risks due to their high surface to volume ratio, which make the particles highly reactive or catalytic. With the widespread use of AuNPs in biomedical fields, it is necessary to fully elucidate their interaction with biological system, in vivo fate and potential toxicological effects on human health, especially on male reproductive function. It has been shown that some nanoparticles have the capacity to accumulate in the testis and potentially show adverse effects on spermatogenesis. However, the effects of AuNPs on testosterone production and mechanism underlying AuNPsinduced spermatogenesis disruption remain to be determined.

Because of its ability to secrete testosterone, which is necessary for spermatogenesis, Leydig cells are ideal target cells to study the in vitro effects of AuNPs on the male reproductive system. In the present study, using TM3 mouse Leydig cells as an in vitro model system, the effects 
A

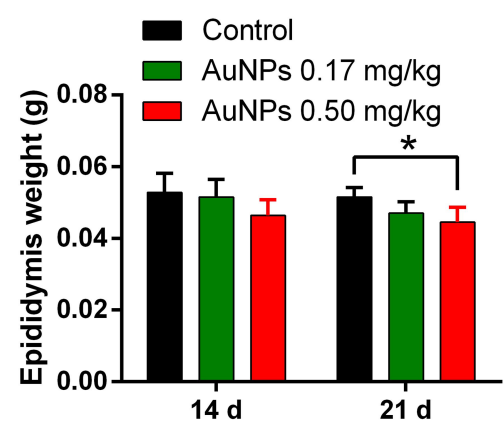

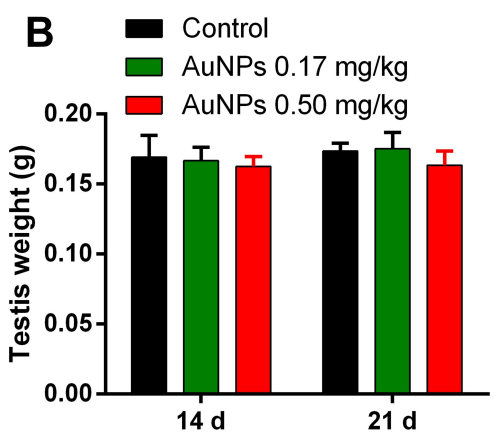

C

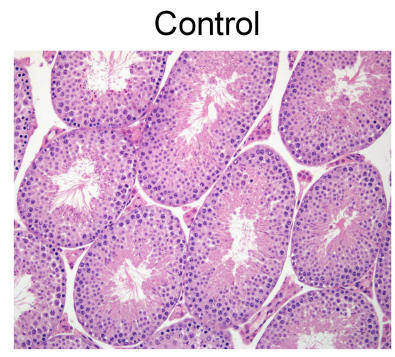

AuNPs $0.5 \mathrm{mg} / \mathrm{kg}(14 \mathrm{~d})$
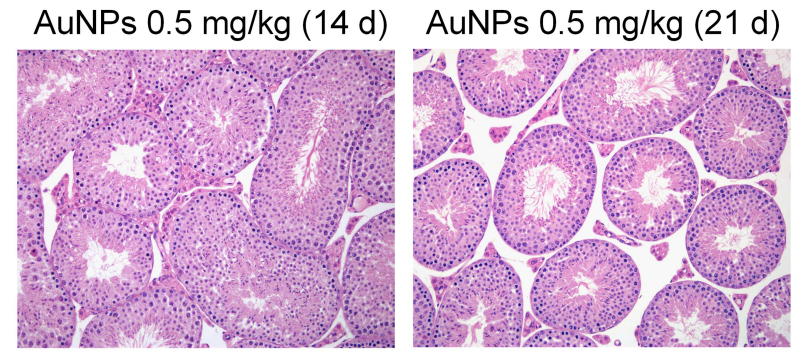

D
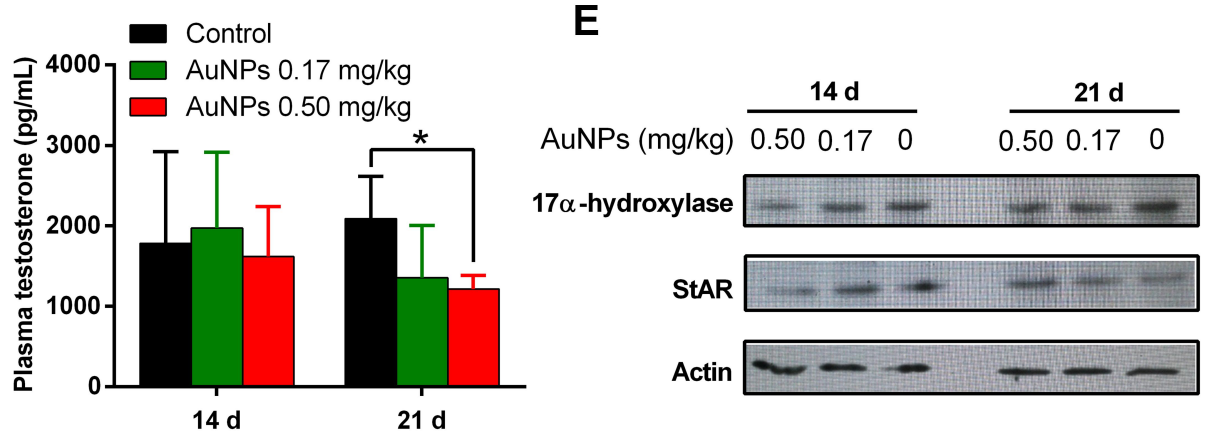

$\mathbf{F}$

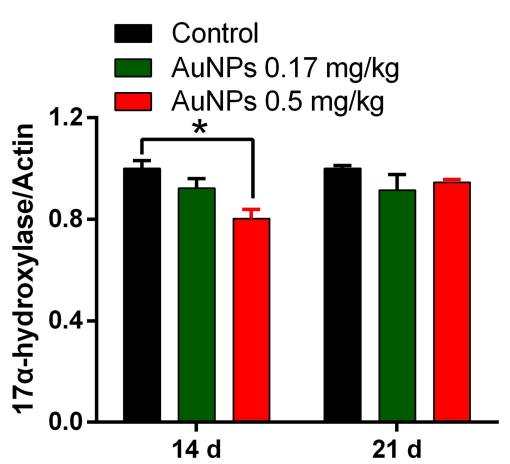

E

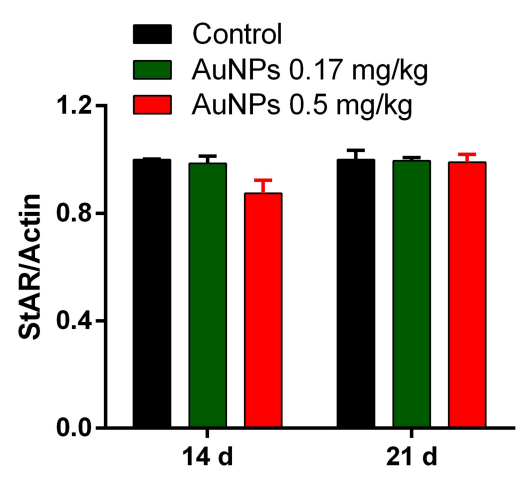

Figure 5 Effects of AuNPs on testicular weight, histology and testosterone production in mice. The weight of epididymis (A) and testis (B) of mice treated with AuNPs on days 14 and $2 \mathrm{I}(\mathrm{n}=6)$. (C) Histopathological images of testicular tissue at 20x magnification (H\&E staining). (D) The plasma testosterone in mice treated with AuNPs was detected using ELISA kit $(n=6)$. (E) Representative Western blot showing the expression of StAR and I7 $\alpha$-hydroxylase protein in testis of mice treated with AuNPs. (F) Relative densitometric analysis of 17-hydroxylase and stAR expression in Western blot. The mean normalized optical density of these protein bands relative to that of Actin bands from the same sample was calculated. Expression levels of these proteins are expressed as fold changes compared with the control group. $*<0.05$, compared to the control group.

of commercial and well-characterized AuNPs on cell uptake, viability, DNA damage and testosterone production were studied. Our results demonstrated that AuNPs were able to be internalized in TM3 cells and saturated after 48-h incubation, and they were packed into the membrane-bound vesicles (eg, endosomes, lysosomes) in the cytoplasm, but not in the nucleus of Leydig cells. Studies have shown that AuNPs and gold nanorods can 
A

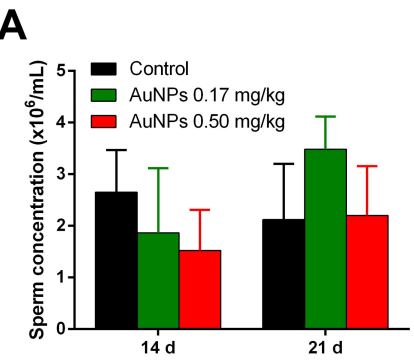

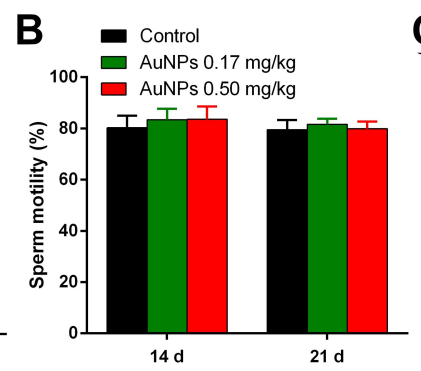

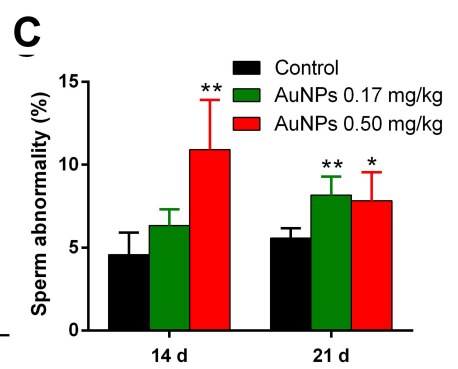

D

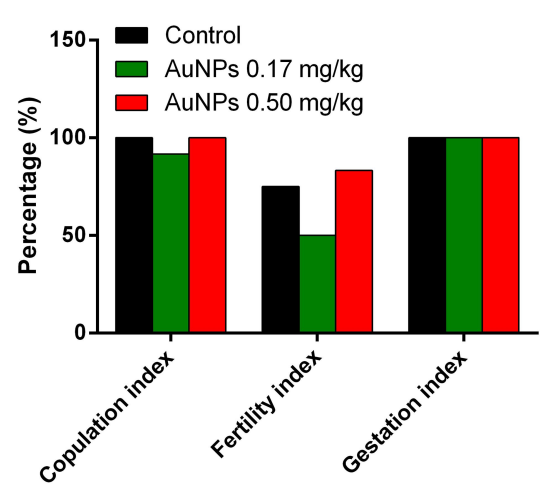

E

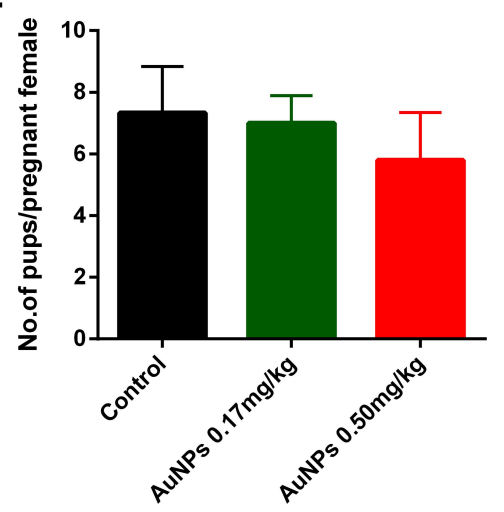

Figure 6 Assessment of sperm analysis, and fertility in mice treated with AuNPs. Sperm concentration (A), sperm motility (B), sperm abnormality (C) and fertility evaluation (D) of control and AuNPs-treated mice $(n=6)$. Sperm concentration as counted with Neubauer haemocytometer. Abnormal sperm was determined by morphologic examination after $1 \%$ eosin staining. Copulation index $(\%)=($ no. of animals with successful copulation/no. of animals paired) $x I 00$. Fertility index $(\%)=($ no. of pregnant females/no. of females with successful copulation) $\times 100$. Gestation index $(\%)=($ no. of females that delivered live pups/no. of pregnant females) $\times 100$. (E) The average number of pups/pregnant female in all the treatment groups $(n=6)$. $* P<0.05, * * P<0.01$, compared to the control group.

enter cells and be trapped in vesicles, but not in nuclei. $^{36-38}$ This observation is also consistent with our previous findings in HepG2 hepatoma cells ${ }^{11}$ and suggests that the internalization of AuNPs in Leydig cells may be medicated by receptor-mediated endocytosis. ${ }^{38,39}$ However, it was reported that AuNPs can be detected inside the nucleus of human sperm after incubation. ${ }^{40}$ Compared with other cells, the internalization of AuNPs in sperm cells is relatively complex, which is related not only to physicochemical properties of NPs, but also to the state of sperm membrane. Acrosome reaction can change composition, fluidity and charge of sperm membrane, which may prompt particles to enter sperm cells. TEM showed that bioconjugated AuNPs successfully penetrated the nuclear membrane in acrosome-reacted sperms, but not in sperm at other stages. ${ }^{41}$

Many engineered NPs have been shown to interact directly or indirectly with DNA, resulting in genotoxic effects such as DNA breaks, point mutations and oxidative DNA adducts. ${ }^{42,43}$ In this study, although AuNPs were not found in the nucleus of TM3 cells, comet assay demonstrated that they were able to induce time - and concentration - dependent DNA damage, suggesting that it is likely due to the indirect interactions. In addition, AuNPs also exhibited concentration-dependent cytotoxicity against TM3 cells, which may be the result of DNA damage. If DNA damage occurs in sperm, it may cause spermatogenic defects and eventually lead to dominant lethal or adverse pregnancy outcomes. ${ }^{44}$ Evidence suggests that DNA fragmentation in spermatozoa is associated with poor pregnancy outcomes, including early embryo death, poor embryo development, and poor implantation. ${ }^{45}$ Semen samples from subfertile men have considerably more DNA damage than semen from fertile controls. In order to explore the molecular mechanisms underlying DNA damage and cytotoxicity induced by AuNPs, we further analyzed their effects on ROS production, apoptosis and cell cycle. Our data demonstrated that AuNPs treatment did not induce obvious apoptosis in TM3 cells, but significantly enhanced the intracellular ROS production, which may indirectly lead to DNA damage and cell death. It was reported that oxidative damage to cellular DNA can lead to DNA changes such as base modification, DNA sequence rearrangement, miscoding of DNA lesion, gene duplication and oncogenes activation. ${ }^{46}$ Meanwhile, the cell cycle of TM3 cell treated with $12.5 \mu \mathrm{g} / \mathrm{mL}$ AuNPs 
was blocked at $\mathrm{S}$ phase, due to increased unscheduled DNA synthesis for repairing damaged DNA. In general, the production of ROS is thought to be the major cause of nano-toxicity, and the unstable ROS molecules typically do not travel far beyond their site of formation, ${ }^{47}$ which can induce or exacerbate NPs-induced inflammation. In addition, DNA damage may be accompanied by DNA repair that collectively contribute to slow cell growth but without significant apoptosis. With the prolongation of exposure time and accumulation of DNA damage, we expect that DNA repair capacity reaches saturation and then cell necrosis have also emerged.

It is known that the Leydig cells in the testes are responsible for the synthesis and secretion of the male sex hormone testosterone. In this study, AuNPs treatment significantly reduced the production of testosterone in TM3 Leydig cells in vitro, and repeated dose of AuNPs in male BALB/c mice also significantly reduced plasma testosterone levels. Consistent with our results, Behnammorshedi et $\mathrm{al}^{48}$ also showed that the testosterone levels in the blood samples of male Wistar rats receiving repeated intraperitoneal injection of AuNPs (100 ppm) significantly decreased compared to the control $(P=$ 0.001). However, Li et $\mathrm{al}^{21}$ reported that PEG-NH2 @,AuNPs treatment significantly elevated plasma testosterone levels in male mice compared with HBS control or mPEG@AuNPs treatment. This inconsistency may be due to the specific coating of $\omega$-aminoethyl $\left(\mathrm{NH}_{2}\right)$ on the surface of AuNPs. In Leydig cells, luteinizing hormone (LH) binds to its receptor and initiates the production of pregnenolone by increasing the expression of steroidogenic acute regulatory protein (StAR), which promotes the transfer of cholesterol to the inner mitochondrial membrane. Pregnenolone is then converted to dehydroepiandrosterone (DHEA) in a two-step process mediated by $17 \alpha$ hydroxylase $(\mathrm{P} 450 \mathrm{c} 17)$, and then rapidly converted to testosterone via the intermediates androstenediol and androstenedione mediated by $3 \beta$-hydevrepoxysteroid dehydevrepogenase isomerase $(3 \beta$-HSD) and $17 \beta$ hydevrepoxysteroid dehydevrepogenase (17 $\beta$-HSD). ${ }^{35,49}$ To further elucidate the molecular mechanism underlying AuNPs induced testosterone production inhibition, the expression of two important proteins (StAR and $17 \alpha-$ hydroxylase) in testosterone synthesis process were analyzed in both TM3 cells and testicular tissue of male mice after AuNPs treatment. Our in vitro and in vivo results consistently demonstrated that AuNPs treatment had no significant effect on the expression of stAR, but significantly reduced the expression of $17 \alpha$-hydroxylase in Leydig cells, which may inhibit the conversion of pregnenolone to DHEA and ultimately reduce the level of testosterone. It should be also noted that hormone levels could be regulated by the hypothalamic-pituitary-testis axis, and the reduction of testosterone levels might also be indirectly attributed to a decrease in the secretion of luteinizing hormone (LH) and follicle-stimulating hormone (FSH), which needs to be further excluded in future studies.

BTB is the physical barrier between the blood vessels and the seminiferous tubules in the animal testes, which is formed by tight junction, adhesion junction and gap junction between sertoli cells. ${ }^{50}$ This barrier can prevent cytotoxic agents from entering seminiferous tubules, maintain fluid composition in the lumen of seminiferous tubules, and prevent germ cell maturation antigen and autoimmune response. NPs exposure can induce inflammatory response and promote cytokine secretion, thereby expanding the size of BTB gap. ${ }^{51}$ It was also reported that testosterone can strengthen the junction integrity of the BTB. ${ }^{52}$ In the in vivo biodistribution study, both ICP-MS and TEM measurement results demonstrated that AuNPs were able to accumulate in the testes and stay afterwards for a long period of time. For instance, after the recovery period (day 21), the $\mathrm{Au}$ content in testis was comparable or even higher than that after the end of AuNPs exposure (day 14), which was consistent with previous reports, ${ }^{21}$ and can be attributed to the prolonged blood circulation of AuNPs. In addition, plasma testosterone levels were significantly reduced in the $0.50 \mathrm{mg} / \mathrm{kg}$ AuNPs group compared to the PBS control group, which may be due to the inhibition of testosterone synthesis by down-regulating the expression of $17 \alpha$-hydroxylase in Leydig cells. Although the exact mechanism how AuNPs enter the testis is not clear, it is speculated that the interplay of plasma testosterone reduction and testicular inflammatory response after AuNPs treatment may lead to the temporary enlargement or opening of BTB gap.

Since AuNPs can accumulate in the testis and inhibit testosterone production, their effects on male reproductive functions such as sperm quality and fertility need to be further evaluated. It was reported that $\mathrm{TiO}_{2}$ NPs affected not only the contemporary reproductive function, but also the reproductive function of the next two generations after prenatal exposure in animal studies. ${ }^{44,53}$ Repeated intravenous administration of $45 \mathrm{mg} / \mathrm{kg}$ PEG-NH $\mathrm{NH}_{2} @$ AuNPs $(14 \mathrm{~nm})$ elevated plasma testosterone levels in male mice 
without affecting fertility. ${ }^{21}$ On the other hand, there are also NPs that have protective effects on the reproductive system. For example, $\mathrm{C}_{60}$ fullerene could restore the sperm motility, epididymal sperm concentration and Johnsen's testicular score in diabetic rats. ${ }^{54}$ SeNPs with antioxidant potential are able to protect reproductive system by preventing lipid peroxidation (LPO) and reducing peroxynitrite (ONOO) levels. ${ }^{55,56}$ In this study, we demonstrated that AuNPs treatment did not cause significant changes in testicular weight, histology, sperm concentration and sperm motility, but significantly increased the rate of epididymal sperm abnormalities. The exact reason why AuNPs affect the quality of epididymal sperm is still unclear. We speculate that this may be related to the decrease of testosterone level and the increase of ROS production caused by exposure to AuNPs. Testosterone is necessary for differentiation of spermatogonia and required to maintain good semen quality. Therefore, the inhibition of testosterone production by AuNPs may affect sperm quality. ROS are the harmful byproducts of oxygen metabolism and high levels of ROS can lead to sperm damage and infertility. Oxidative stress in the male germ line leads to the induction of damage to the sperm plasma membrane and a loss of genetic integrity in the nucleus and mitochondria. Spermatic DNA damage increases with elevated ROS levels, which usually occur either during intratesticular spermatogenesis or during semen maturation and transport. ${ }^{57}$ However, it is worth mentioning that in this study, AuNPs did not affect the fertility of mice, including copulation index, fertility index and gestation index. The average number of offspring in the $0.5 \mathrm{mg} / \mathrm{kg}$ AuNPs group decreased slightly, which may be due to fewer fertilized eggs or potential embryo-lethality. It should be noted that AuNPs were given only for 14 days in this study, and long-term or high-dose exposure may further increase their testicular accumulation, interfere with testosterone production, reduce sperm quality and ultimately affect fertility. Therefore, the potential negative impact of AuNPs on male reproductive function should be carefully considered in their biomedical applications.

\section{Conclusion}

In summary, AuNPs could be internalized in endosomes/ lysosomes, induce autophagosome formation, enhance ROS production, and disrupt cell cycle, eventually leading to DNA damage and cytotoxicity in TM3 Leydig cells. In addition, AuNPs significantly inhibited the synthesis of testosterone in TM3 cells by reducing the expression of $17 \alpha$-hydroxylase. Furthermore, repeated administration of AuNPs were able to accumulate in the testes of male mice, reduce plasma testosterone levels and increase the rate of epididymal sperm malformation, without affecting fertility.

\section{Acknowledgments}

This work was supported by the National Natural Science Foundation of China (81572617, 81630101), Sichuan Science and Technology Program (2019JDRC0019), Innovation Spark Project of Sichuan University (2019SCUH0015), 1·3·5 project for disciplines of excellence, West China Hospital, Sichuan University (ZYJC18026), and $1 \cdot 3 \cdot 5$ project for disciplines of excellence-Clinical Research Incubation Project, West China Hospital, Sichuan University (2020HXFH023).

\section{Disclosure}

The authors declare that they have no conflicts of interest.

\section{References}

1. Singh BN, Prateeksha GVK, Chen J, Atanasov AG. Organic nanoparticle-based combinatory approaches for gene therapy. Trends Biotechnol. 2017;35(12):1121-1124. doi:10.1016/j.tibtech.20 17.07.010

2. Wang Z, Wang Z, Lu WW, Zhen W, Yang D, Peng S. Novel biomaterial strategies for controlled growth factor delivery for biomedical applications. Npg Asia Mater. 2017;9(10):e435. doi:10.1038/am.20 17.171

3. Chen WH, Lei Q, Luo GF, et al. Rational design of multifunctional gold nanoparticles via host-guest interaction for cancer-targeted therapy. ACS Appl Mater Interfaces. 2015;7(31):17171-17180. doi:10.1021/acsami.5b04031

4. Hwang S, Nam J, Jung S, Song J, Doh H, Kim S. Gold nanoparticle-mediated photothermal therapy: current status and future perspective. Nanomedicine (Lond). 2014;9(13):2003-2022. doi:10.22 17/nnm.14.147

5. Wilson R. The use of gold nanoparticles in diagnostics and detection. Chem Soc Rev. 2008;37(9):2028-2045. doi:10.1039/b712179m

6 . Vines T, Faunce T. Assessing the safety and cost-effectiveness of early nanodrugs. $J$ Law Med. 2009;16(5):822-845.

7. Hanley C, Thurber A, Hanna C, Punnoose A, Zhang J, Wingett DG. The influences of cell type and $\mathrm{ZnO}$ nanoparticle size on immune cell cytotoxicity and cytokine induction. Nanoscale Res Lett. 2009;4 (12):1409-1420. doi:10.1007/s11671-009-9413-8

8. Chithrani BD, Ghazani AA, Chan WC. Determining the size and shape dependence of gold nanoparticle uptake into mammalian cells. Nano Lett. 2006;6(4):662-668. doi:10.1021/n1052396o

9. Cho W, Cho M, Jeong J, et al. Size-dependent tissue kinetics of PEG-coated gold nanoparticles. Toxicol Appl Pharm. 2010;245 (1):116-123. doi:10.1016/j.taap.2010.02.013

10. Khanna P, Ong C, Bay BH, Baeg GH. Nanotoxicity: an interplay of oxidative stress, inflammation and cell death. Nanomaterials (Basel). 2015;5(3):1163-1180. doi:10.3390/nano5031163

11. Xia Q, Li H, Liu Y, Zhang S, Feng Q, Xiao K. The effect of particle size on the genotoxicity of gold nanoparticles. J Biomed Mater Res A. 2017;105(3):710-719. doi:10.1002/jbm.a.35944

12. Howards SS. Treatment of male infertility. $N$ Engl J Med. 1995;332 (5):312-317. doi:10.1056/NEJM199502023320507 
13. Guz J, Gackowski D, Foksinski M, et al. Comparison of oxidative stress/DNA damage in semen and blood of fertile and infertile men. PLoS One. 2013;8(7):e68490. doi:10.1371/journal.pone.0068490

14. Wright C, Milne S, Leeson H. Sperm DNA damage caused by oxidative stress: modifiable clinical, lifestyle and nutritional factors in male infertility. Reprod Biomed Online. 2014;28(6):684-703. doi:10.1016/j.rbmo.2014.02.004

15. Hsin YH, Chen CF, Huang S, Shih TS, Lai PS, Chueh PJ. The apoptotic effect of nanosilver is mediated by a ROS- and JNK-dependent mechanism involving the mitochondrial pathway in NIH3T3 cells. Toxicol Lett. 2008;179(3):130-139. doi:10.1016/j. toxlet.2008.04.015

16. van Gelder MM, van Rooij IA, Miller RK, Zielhuis GA, de Jong-van DBL, Roeleveld N. Teratogenic mechanisms of medical drugs. Hum Reprod Update. 2010;16(4):378-394. doi:10.1093/humupd/dmp052

17. Wiwanitkit V, Sereemaspun A, Rojanathanes R. Effect of gold nanoparticles on spermatozoa: the first world report. Fertil Steril. 2009;91 (1):e7-8. doi:10.1016/j.fertnstert.2007.08.021

18. Brune D, Samsahl K, Wester P. A comparison between the amounts of $\mathrm{As}, \mathrm{Au}, \mathrm{Br}, \mathrm{Cu}, \mathrm{Fe}, \mathrm{Mo}$, Se and $\mathrm{Zn}$ in normal and uraemic human whole blood by means of neutron activation analysis. Clin Chim Acta. 1966;13(3):285-291. doi:10.1016/0009-8981(66)90207-5

19. Kasperek K, Iyengar GV, Kiem J, Borberg H, Feinendegen LE. Elemental composition of platelets. Part III. Determination of Ag, $\mathrm{Au}, \mathrm{Cd}, \mathrm{Co}, \mathrm{Cr}, \mathrm{Cs}, \mathrm{Mo}, \mathrm{Rb}, \mathrm{Sb}$, and $\mathrm{Se}$ in normal human platelets by neutron activation analysis. Clin Chem. 1979;25(5):711-715. doi:10. 1093/clinchem/25.5.711

20. Ganong WF. Ganong's Review of Medical Physiology. 24 ed. 2012.

21. Li WQ, Wang F, Liu ZM, Wang YC, Wang J, Sun F. Gold nanoparticles elevate plasma testosterone levels in male mice without affecting fertility. Small. 2013;9(9-10):1708-17014. doi:10.1002/smll.20 1201079

22. Lee JK, Kim TS, Bae JY, et al. Organ-specific distribution of gold nanoparticles by their surface functionalization. $J$ Appl Toxicol. 2015;35(6):573-580. doi:10.1002/jat.3075

23. Leclerc L, Klein JP, Forest V, et al. Testicular biodistribution of silica-gold nanoparticles after intramuscular injection in mice. Biomed Microdevices. 2015;17(4):66. doi:10.1007/s10544-0159968-3

24. Chen H, Dorrigan A, Saad S, Hare DJ, Cortie MB, Valenzuela SM. In vivo study of spherical gold nanoparticles: inflammatory effects and distribution in mice. PLoS One. 2013;8(2):e58208. doi:10.1371/journal.pone.0058208

25. Nazar M, Talebi AR, Hosseini SM, Abbasi A, Khoradmehr A, Danafar AH. Acute and chronic effects of gold nanoparticles on sperm parameters and chromatin structure in Mice. Int $J$ Reprod Biomed (Yazd). 2016;14(10):637-642. doi:10.29252/ijrm.14.10.637

26. Velikorodnaya YI, Pocheptsov AY, Sokolov OI, Bogatyrev VA, Dykman LA. Effect of gold nanoparticles on proliferation and apoptosis during spermatogenesis in rats. Nanotechnol Russia. 2015;10 (9-10):814-819. doi:10.1134/S1995078015050201

27. Xiao K, Luo J, Fowler WL, et al. A self-assembling nanoparticle for paclitaxel delivery in ovarian cancer. Biomaterials. 2009;30 (30):6006-6016. doi:10.1016/j.biomaterials.2009.07.015

28. Liu Q, Li H, Xia Q, Liu Y, Xiao K. Role of surface charge in determining the biological effects of $\mathrm{CdSe} / \mathrm{ZnS}$ quantum dots. Int J Nanomedicine. 2015;10:7073-7088. doi:10.2147/IJN.S94543

29. Gromadzka-Ostrowska J, Dziendzikowska K, Lankoff A, et al. Silver nanoparticles effects on epididymal sperm in rats. Toxicol Lett. 2012;214(3):251-258. doi:10.1016/j.toxlet.2012.08.028

30. Asare N, Instanes C, Sandberg WJ, et al. Cytotoxic and genotoxic effects of silver nanoparticles in testicular cells. Toxicology. 2012;291 (1-3):65-72. doi:10.1016/j.tox.2011.10.022

31. Size- and cell type-dependent cellular uptake, cytotoxicity and in vivo distribution of gold nanoparticles. Int $J$ Nanomed. 2019;14:6957-6970. doi:10.2147/IJN.S214008
32. Latendresse JR, Warbrittion AR, Jonassen H, Creasy DM. Fixation of testes and eyes using a modified Davidson's fluid: comparison with Bouin's fluid and conventional Davidson's fluid. Toxicol Pathol. 2002;30(4):524-533. doi:10.1080/019262302901 05721

33. De Jong WH, Hagens WI, Krystek P, Burger MC, Sips AJ, Geertsma RE. Particle size-dependent organ distribution of gold nanoparticles after intravenous administration. Biomaterials. 2008;29(12):1912-1919. doi:10.1016/j.biomaterials.2007.12.037

34. Lankveld DP, Rayavarapu RG, Krystek P, et al. Blood clearance and tissue distribution of PEGylated and non-PEGylated gold nanorods after intravenous administration in rats. Nanomedicine (Lond). 2011;6 (2):339-349. doi:10.2217/nnm.10.122

35. Waterman MR, Keeney DS. Genes involved in androgen biosynthesis and the male phenotype. Horm Res. 1992;38(5-6):217-221. doi:10. $1159 / 000182546$

36. Alkilany AM, Nagaria PK, Hexel CR, Shaw TJ, Murphy CJ, Wyatt MD. Cellular uptake and cytotoxicity of gold nanorods: molecular origin of cytotoxicity and surface effects. Small. 2009;5 (6):701-708. doi:10.1002/smll.200801546

37. Khan JA, Dr BP, Dr TKD, Dr YS, Dr SM. Molecular effects of uptake of gold nanoparticles in HeLa cells. Chembiochem. 2010;8 (11):1237-12340. doi:10.1002/cbic.200700165

38. Chithrani BD, Chan WC. Elucidating the mechanism of cellular uptake and removal of protein-coated gold nanoparticles of different sizes and shapes. Nano Lett. 2007;7(6):1542-1550. doi:10.1021/ n1070363y

39. Dobrovolskaia MA, McNeil SE. Immunological properties of engineered nanomaterials. Nat Nanotechnol. 2007;2(8):469-478. doi:10.1038/nnano.2007.223

40. Moretti E, Terzuoli G, Renieri T, et al. In vitro effect of gold and silver nanoparticles on human spermatozoa. Andrologia. 2013;45 (6):392-396. doi:10.1111/and.12028

41. Barchanski A, Taylor U, Sajti CL, et al. Bioconjugated gold nanoparticles penetrate into spermatozoa depending on plasma membrane status. J Biomed Nanotechnol. 2015;11(9):1597-1607. doi:10.1166/ jbn.2015.2094

42. AshaRani PV, Low KMG, Hande MP, Valiyaveettil S. Cytotoxicity and genotoxicity of silver nanoparticles in human cells. Acs Nano. 2009;3(2):279-290. doi:10.1021/nn800596w

43. Foldbjerg R, Dang DA, Autrup H. Cytotoxicity and genotoxicity of silver nanoparticles in the human lung cancer cell line, A549. Arch Toxicol. 2011;85(7):743-750. doi:10.1007/s00204-0100545-5

44. Kyjovska ZO, Boisen AM, Jackson P, Wallin H, Vogel U, Hougaard KS. Daily sperm production: application in studies of prenatal exposure to nanoparticles in mice. Reprod Toxicol. 2013;36:88-97. doi:10.1016/j.reprotox.2012.12.005

45. Tesarik J, Mendoza C, Greco E. Paternal effects acting during the first cell cycle of human preimplantation development after ICSI. Hum Reprod. 2002;17(1):184-189. doi:10.1093/humrep/17.1.184

46. Waris G, Ahsan H. Reactive oxygen species: role in the development of cancer and various chronic conditions. J Carcinog. 2006;5(1):14. doi:10.1186/1477-3163-5-14

47. Wells PG, Bhuller Y, Chen CS, et al. Molecular and biochemical mechanisms in teratogenesis involving reactive oxygen species. Toxicol Appl Pharmacol. 2005;207(2 Suppl):354-366. doi:10.1016/ j.taap.2005.01.061

48. Behnammorshedi M, Nazem H, Moghadam MS. The effect of gold nanoparticle on luteinizing hormone, follicle stimulating hormone, testosterone and testis in male rat. Biomedical Research. 2015;26 (2):348-352.

49. Zuber MX, Simpson ER, Waterman MR. Expression of bovine 17 alpha-hydroxylase cytochrome P-450 cDNA in nonsteroidogenic (COS 1) cells. Science. 1986;234(4781):1258-1261. doi:10.1126/ science. 3535074 
50. Sharma S, Hanukoglu A, Hanukoglu I. Localization of epithelial sodium channel $(\mathrm{ENaC})$ and CFTR in the germinal epithelium of the testis, Sertoli cells, and spermatozoa. J Mol Histol. 2018;49 (2):195-208. doi:10.1007/s10735-018-9759-2

51. Park EJ, Bae E, Yi J, et al. Repeated-dose toxicity and inflammatory responses in mice by oral administration of silver nanoparticles. Environ Toxicol Pharmacol. 2010;30(2):162-168. doi:10.1016/j. etap.2010.05.004

52. Meng J, Holdcraft RW, Shima JE, Griswold MD, Braun RE. Androgens regulate the permeability of the blood-testis barrier. Proc Natl Acad Sci $U$ S A. 2005;102(46):16696-16700. doi:10.1073/pnas.0506084102

53. Gao G, Ze Y, Zhao X, et al. Titanium dioxide nanoparticle-induced testicular damage, spermatogenesis suppression, and gene expression alterations in male mice. J Hazard Mater. 2013;258-259:133-143. doi:10.1016/j.jhazmat.2013.04.046
54. Bal R, Turk G, Tuzcu M, et al. Protective effects of nanostructures of hydrated $\mathrm{C}(60)$ fullerene on reproductive function in streptozotocin-diabetic male rats. Toxicology. 2011;282(3):69-81. doi:10.1016/j.tox.2010.12.003

55. Rezvanfar MA, Rezvanfar MA, Shahverdi AR, et al. Protection of cisplatin-induced spermatotoxicity, DNA damage and chromatin abnormality by selenium nano-particles. Toxicol Appl Pharmacol. 2013;266(3):356-365. doi:10.1016/j.taap.2012.11.025

56. Shi LG, Yang RJ, Yue WB, et al. Effect of elemental nano-selenium on semen quality, glutathione peroxidase activity, and testis ultrastructure in male Boer goats. Anim Reprod Sci. 2010;118(2-4):248-254. doi:10.1016/j.anireprosci.2009.10.003

57. Aitken RJ, Baker MA, Sawyer D. Oxidative stress in the male germ line and its role in the aetiology of male infertility and genetic disease. Reprod Biomed Online. 2003;7(1):65-70. doi:10.1016/ S1472-6483(10)61730-0

\section{Publish your work in this journal}

The International Journal of Nanomedicine is an international, peerreviewed journal focusing on the application of nanotechnology in diagnostics, therapeutics, and drug delivery systems throughout the biomedical field. This journal is indexed on PubMed Central, MedLine, CAS, SciSearch ${ }^{\mathbb{R}}$, Current Contents ${ }^{\mathbb{R}} /$ Clinical Medicine, $^{-}$
Journal Citation Reports/Science Edition, EMBase, Scopus and the Elsevier Bibliographic databases. The manuscript management system is completely online and includes a very quick and fair peer-review system, which is all easy to use. Visit http://www.dovepress.com/ testimonials.php to read real quotes from published authors. 